\title{
Anti-Leptospira spp antibodies in cart horses of the city of Guaíba, Rio Grande do Sul State, Brazil
}

\author{
Anticorpos anti-Leptospira spp em cavalos carroceiros \\ da cidade de Guaíba, Rio Grande do Sul, Brasil

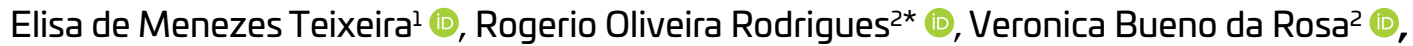 Angélica Cavalheiro Bertagnolli2 ${ }^{2}$

\begin{abstract}
The objective of this study was to evaluate the occurrence of antibodies against Leptospira spp in horses used by communities of informal waste collectors who use horse-drawn carts in Guaíba, Rio Grande do Sul. Additionally, interviews were conducted with owners to assess the characteristics of the horses, their environment, and work. Serological testing for Leptospira spp. was performed on blood samples collected from 54 horses using the microscopic agglutination test. Results showed that $50.0 \%$ of the horses were seropositive for Leptospira spp and the most frequent serogroup was Leptospira Canicola (88. 8\%), followed by Leptospira Pyrogenes (11.1\%), Leptospira Bataviae (7.4\%), Leptospira Hebdomadis (7.4\%), Leptospira Icterohaemorrhagiae (3.7\%), Leptospira Australis (3.7\%), Leptospira Pomona (3.7\%) and Leptospira Copenhageni (3.7\%). There were no statistically significant associations between seropositivity for Leptospira spp and age, gender, body score, water source, type of food storage, cohabitation with dogs, rodent infestation, residential flooding, and waste removal services. The prevalence of the Canicola serogroup, as well as a large number of dogs in close relationship with the horses and the waste collectors, draws attention to the potential of these animals to become a source of Leptospira spp. infection in humans and other animals.
\end{abstract}

KEYWORDS: carts, sanitation, leptospirosis, serogroup, zoonosis

RESUMO: O objetivo deste estudo foi avaliar a ocorrência de anticorpos contra Leptospira spp em cavalos utilizados por comunidades de carroceiros, catadores informais que utilizam carroças puxadas a cavalo, em Guaíba, Rio Grande do Sul. Além disso, foram realizadas entrevistas com os proprietários para avaliar as características dos cavalos, o ambiente e o trabalho. Teste sorológico para Leptospira spp. foi realizada em amostras de sangue coletadas de 54 cavalos utilizando o teste de aglutinação microscópica. Os resultados mostraram que 50,0\% dos cavalos eram soropositivos para Leptospira spp e o sorogrupo mais frequente foi Leptospira canicola (44, 4\%), seguido por Leptospira pyrogenes $(5,5 \%)$, Leptospira bataviae $(3,7 \%)$, Leptospira hebdomadis $(3,7 \%)$, Leptospira icterohaemorrhagiae $(1,8 \% ; 1 / 54)$, Leptospira australis $(1,8 \%)$ e Leptospira pomona $(1,8 \%)$. Não houve associação estatisticamente significante entre soropositividade para Leptospira spp e idade, sexo, escore corporal, fonte de água, armazenamento de alimentos, convivência com cães, infestação de roedores, serviços de inundação residencial e remoção de resíduos. A prevalência do sorogrupo Leptospira canicola, bem como o grande número de cães em estreita relaçáo com os cavalos, os carroceiros chamam a atenção para o potencial desses animais como fonte de Leptospira spp. infecção em humanos e outros animais.

PALAVRAS-CHAVE: vagão, saneamento, leptospirose, sorogrupo, zoonose

Leptospirosis is a worldwide zoonosis of great sanitary and economic importance that affects human beings and domestic animals (ELLIS, 2015). The disease is caused by pathogenic bacteria of the genus Leptospira, which are classified into serogroups and serovars that vary depending on the diversity of environments and hosts (JARA et al., 2019). In urban areas, the proximity between humans and animals in poor housing conditions increases the risk of infection and the spread of bacteria (MENY et al., 2019). Scenarios like these are found in territories occupied by local informal waste collectors who use horses to transport their cargo in wagons. Horses infected with Leptospira may play a role in the transmission of the bacteria to these workers and other animals. In turn, even asymptomatic human carriers

'Secretaria Municipal de Saúde da Prefeitura Municipal de Guaíba - Guaíba (RS), Brazil. 
can spread the bacteria through their urine for several weeks (YAN et al., 2010).

Having this context as background, this study aimed to evaluate the occurrence of antibodies against Leptospira spp in horses used by communities of informal waste collectors who use horse-drawn carts, in Guaíba, Rio Grande do Sul.

A cross-sectional study was carried out with serological testing of cart horses and interviews with their owners and caretakers. Guaíba is one of the 34 municipalities that are part of the metropolitan region of Porto Alegre. It is located on the right bank of Guaíba Lake, which is an estuary of the Gravataí, Sinos, Caí, Jacuí, and Delta do Jacuí rivers, passes by Lagoa dos Patos lake and ends at the Atlantic Ocean.

We identified and visited residences with cart horses in the following neighborhoods: Vila Nova Guaíba, Vila São Francisco, Vila Vera Cruz, Vila do Ipê, Invasão da Cohab, Vila São Jorge, Pedras Brancas, Moradas da Colina, Ermo and Columbia.

The sample size was based on the number cart horses estimated by home visits in Vila Nova Guaíba, Vila São Francisco, Vila Vera Cruz, Vila do Ipê, Invasão da Cohab, Vila São Jorge, Pedras Brancas, Moradas da Colina, Ermo and Columbia. A total of 66 cart horses distributed in 41 homes were identified.

The population size was calculated by the Epitools epidemiological calculator (https://epitools.ausvet.com.au/), with a 95\% confidence interval and expected prevalence of $10 \%$. This resulted in a sample of 23 animals from the total of 66 cart horses estimated during home visits in Vila Nova Guaíba, Vila São Francisco, Vila Vera Cruz, Vila do Ipê, Invasão da Cohab, Vila São Jorge, Pedras Brancas, Moradas da Colina, Ermo and Columbia.

A total of 54 cart horses were evaluated per convenience. None had been vaccinated against leptospirosis. The owners and caretakers of these horses who agreed to participate in the study were interviewed individually to gather information about the characteristics of the animals, their environment, and work. Horses underwent a physical examination to check for eye lesions and assess body condition, rectal temperature, hydration, and the color of the mucous membranes.

Blood samples were collected for serological tests at the first evaluation and approximately 45 to 60 days after the first tests. Trained veterinary physicians undertook all sampling and the Leptospirosis laboratory at the Instituto de Pesquisas Desidério Finamor in Eldorado do Sul was responsible for serological testing.

Blood serum was used to test for anti-Leptospira antibodies through the microscopic agglutination test (MAT; ELLINGHAUSEN; MCCULLOUGH, 1965). Serum samples were analyzed to detect the presence of 18 serovars of Leptospira pathogens with the following antigens: Autumnalis, Australis, Bataviae, Canicola, Castellonis, Celledoni, Copenhageni, Gripp otyphosa, Hardjo, Hebdomadis, Icterohaemorrhagiae,Javanica, Pa nama,Pomona, Pyrogenes, Serjoe, Tarassovi, and Wolff. Animals that presented $50 \%$ or more agglutinated Leptospiras Spp in a $1 / 100$ dilution in the microscopic field, in at least one of the serological evaluations, were considered positive for Leptospira spp. To assess possible associations between a positive Leptospira spp result and animal and environmental characteristics, and type of work, we used the Fisher Exact Test $(\mathrm{P}<0.05)$.

This study was carried out with the support of the local government organs overseeing health and environmental issues, the Secretarias de Saúde e do Meio Ambiente. Our research was carried out according to the guidelines of the ethics committee of the IPVDF, Comitê de Ética no Uso de Animais (CEUA), and registered under number 12/2016. It was also approved by the ethics committee of the Ritter dos Reis University Center/RS, Comitê de Ética em Pesquisa com Seres Humanos, and registered under the numbers CAAE 91930918.3.0000.5309 and 2.995.019.

Serological examinations revealed that $50 \%$ (27/54) of the animals presented positive reactions to one or more serogroups of Leptospira in at least one of the evaluations, with titers ranging from 1:100 to 1:400. Although the frequency of detection of anti- Leptospira spp antibodies was lower than those reported by other studies involving cart horses from other cities in Brazil (HASHIMOTO et al., 2007; LASTA et al., 2013; FINGER et al., 2014; DIAS et al., 2015), it is still concerning. A large portion of the population from the neighborhoods we tested sustain themselves with load transport and the horses are the main source of traction. These animals maintain close and constant contact with their owners and often share the same home and surrounding environment. Our detection of reactive animals indicates contact with the bacteria and also shows that they circulate in environments where humans and other animals are also exposed. Besides this, if they become chronic hosts and continuously eliminate the bacteria in their urine, the horses can contribute to the transmission of the bacteria to humans and other animals (ELLIS, 2015).

The serogroups were Canicola (88.9\%; 24/27), Pyrogenes (11.1\%; 3/27), Bataviae (7.4\%; 2/27), Hebdomadis (7.4\%; 2/27), Icterohaemorrhagiae (3.7\%; 1/27), Australis (3.7\%; 1/27), Pomona (3.7\%; 1/27) and Copenhageni (3.7\%; 1/27). Of these, $14.8 \%$ (4/27) of the horses tested positive for more than one serogroup. The predominance of the Canicola serogroup, for which dogs are maintenance hosts (ELLIS, 2015), suggests the role of dogs in the transmission to horses. This is reinforced by the fact that $90 \%$ of the horses we tested cohabited with dogs. Among the horses that tested positive, 81. 5\% (22/27) cohabited with dogs (Tabela 1). Of these, 48.1\% (13/27) also had contact with cats, $44.4 \%$ (12/27) with chickens, $37.0 \%$ $(12 / 27)$ with other horses, and $11.1 \%$ (3/27) with pigs.

In other cart-horse populations, researchers reported a predominance of the Icterohaemorrhagiae serogroup (FINGER et al., 2014; DIAS et al., 2015). Rodents are the main maintenance hosts of this serogroup (ELLIS, 2015; BOEY et al, 2019). In our study, the only horse which tested positive for Icterohaemorrhagiae serogroup was kept in an environment where rodents were reported.

Antibodies against Bataviae, Australis, Pomona and Copenhageni serogroups have also been previously detected in 
other Brazilian studies involving cart horses (HASHIMOTO et al., 2007; CASELANI et al., 2012; DIAS et al., 2015). Our findings reinforce the importance of rodent control in homes, since infected mice and rats are reservoirs for these serogroups and also possible sources of infection (FAINE et al., 1999; BENACER et al, 2016). The caretakers of these animals reported the presence of rodents in the environment where the animals were kept, which may explain this result.

The Pyrogenes serogroup has been previously detected in cart horses in Brazil, but at a lower frequency than in our study (HASHIMOTOET AL, 2007; CASELANI et al., 2012; FINGER et al., 2014; DIAS et al., 2015). In other studies, the detection of this serogroup has been related to cross-reactivity with the serogroup Icterohaemorrhagiae (Jorge et al. 2011; Lelu et al. 2015).

Previous reports have described finding the serogroup L. Hebdomadis in cart horses (CASELANI et al., 2012 DIAS et al., 2015). This serogroup has been associated with incidental infections in cattle, dogs and humans (ELLIS, 2015; GUERNIER et al., 2018).

Clinical manifestations related to leptospirosis in seropositive animals were rare and unspecific as previously reported elsewhere (LASTA et al., 2013). This also indicates that there were no cases of active infection during the period of our research.

In urban spaces, environments in which there is waste management and accumulation, flooding, rodents, and contact between different animal species increase the likelihood of leptospiral dispersion and incidental infections in humans and domestic animals (Rafizah et al. 2013; BARRAGAN et al., 2017). We found no significant association between and environmental or management characteristics seropositivity for Leptospira (Table 1). Although no significant association has been demonstrated, these aspects cannot be neglected, as they are known risk factors for Leptospirosis and were present in most of the homes visited. The lack of statistical significance may be related to the reduced number of evaluated animals, interview bias or to observations' homogeneity.

The risk of seropositivity for Leptospira spp has been described as higher for mares and gelding males and increases with the age of horses (Langoni et al., 2001; Sequeira et al., 2020). However, our results did not show this relationship and corroborate similar data about cart horses from other regions of Brazil (Pinho et al., 2014; Dias et al., 2015). This is probably due to the lower number of animals we assessed and the homogeneity of the population.
In conclusion, results show that these cart horses were exposed to Leptospira spp. and also indicate that the bacteria are present in the environments where the horses, people, and other animals interact. The predominance of the Canicola serogroup and the expressive proportion of residences with dogs draws attention to the potential of these animals to become a source of Leptospira spp. infection.

Table 1. Horses characteristics, management and seropositivity for Leptospira spp.

\begin{tabular}{|c|c|c|c|}
\hline Variable & $\mathbf{n}$ & $\begin{array}{c}\text { Seropositivity } \\
\text { n (\%) }\end{array}$ & $\mathbf{p}$ \\
\hline Gender & & & 0.25 \\
\hline Female & 8 & $2(25.0)$ & \\
\hline Male & 46 & $25(54.3)$ & \\
\hline Age & & & 0.27 \\
\hline$<3$ years & 9 & $6(66.6)$ & \\
\hline$>3$ years & 36 & $15(41.7)$ & \\
\hline \multicolumn{4}{|l|}{ Body Score } \\
\hline Lean & 16 & $6(37.5)$ & 0.24 \\
\hline Moderate & 37 & $21(56.7)$ & \\
\hline \multicolumn{4}{|l|}{ Water source } \\
\hline Piped & 42 & $24(57.1)$ & 0.09 \\
\hline Well, ditch or flooded area & 11 & $3(27.3)$ & \\
\hline \multicolumn{4}{|l|}{ Food storage } \\
\hline Closed container & 46 & $23(50.0)$ & 1.00 \\
\hline Open container & 2 & $1(50.0)$ & \\
\hline Cohabitation with dogs & & & 0,67 \\
\hline Yes & 48 & $23(47.9)$ & \\
\hline No & 6 & $4(66.7)$ & \\
\hline Rodents in the residence & & & 0.35 \\
\hline Yes & 14 & $22(55.0)$ & \\
\hline No & 40 & $5(35.7)$ & \\
\hline Flooding in the residence & & & 0.78 \\
\hline Yes & 24 & $16(53.3)$ & \\
\hline No & 30 & $11(45.8)$ & \\
\hline Waste removal services & & & 1.00 \\
\hline Yes & 21 & $17(51.5)$ & \\
\hline No & 33 & $10(47.6)$ & \\
\hline
\end{tabular}

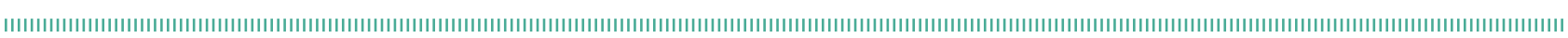

\section{REFERENCES}

BENACER, D. et al. Determination of Leptospira borgpetersenii serovar Javanica and Leptospira interrogans serovar Bataviae as the persistent Leptospira serovars circulating in the urban rat populations in Peninsular Malaysia. Parasites and Vectors, v.9, 117, 201. from:<https://www.ncbi.nlm. nih.gov/pmc/articles/PMC4772511/pdf/13071_2016_ Article_1400.pdf>. Accessed: Apr. 11, 2020. doi:10.1186/ s13071-016-1400. 
BOEY, K. et al. Leptospira infection in rats: A literature review of global prevalence and distribution. PLOS Neglected Tropical Diseases, v. 9, p.1-24, 2019. Available from:<https:// journals.plos.org/plosntds/article/file?id=10.1371/journal. pntd.0007499\&type=printable >Accessed: Apr. 02, 2020. doi: $10.1371 /$ journal.pntd.0007499.

CASELANI, K. et al. Estudo soroepidemiológico de leptospirose em equinos utilizados para tração urbana. Revista do Instituto Adolfo Lutz, v.71, n.3, p.582-587, 2012. Available from:<http://periodicos.ses.sp.bvs.br/pdf/rial/v7 1n3/v71n3a20. pdf>. Accessed: Mar. 03, 2019.

DIAS, H.L.T. et al. Inquérito sorológico para leptospirose em condutores de carroças e equídeos de tração em Belém, Pará.

Revista de Ciências Agrárias/Amazonian Journal of Agricultural Environmental Science, v.58, n.4, p.396-401, 2015. Availablefrom:<http://periodicos.ses.sp.bvs.br/pdf/ rial/v7 1n3/v71 n3a20.pdf>. Accessed: Mar. 29, 2020. doi: 10.4322/rca.2013.

FAINE, S.; ADLER, B.; BOLIN, C.; PEROLAT, P. Leptospira and leptospirosis. Boca Raton: CRC Press, 1999.

FINGER, M.A.P. et al. Serological and molecular survey of leptospira spp. among cart horses from an endemic area of human leptospirosis in curitiba, southern Brazil. Revista do Instituto de Medicina Tropical de São Paulo, v.56, n.6, p. 473-476, 2014. Available from:< http://periodicos.ses.sp.bvs. br/pdf/rial/v7 1n3/v7 1n3a20.pdf >. Accessed: Mar. 25, 2020. doi. 10.1590/S0036-46652014000600003.

GUERNIER, V. et al. A systematicreview of human and animal leptospirosisin the Pacific Islands reveals pathogenand reservoir diversity. PLOS Neglected Tropical Diseases. May, 14, 2018. Available from:< https://journals.plos.org/plosntds/ article?id=10.1371/journal.pntd.0006503>. Accessed: Aug, 27, 2020. doi: 10.1371 /journal.pntd.0006503journal. pntd.0006503.

ELLINGHAUSEN, H.C; MCCULLOUGH, W.G. Nutrition of leptospira pomona and growth of 13 other serotypes: fractionation of oleic albumin complex and a medium of bovine albumin and polysorbate 80 . American Journal of Veterinarye Research, v.26, p. 45-51, 1965.

ELLIS, W. A. Animal Leptospirosis. In: Adler, B. Leptospira and leptospirosis. Springer Verlag; 2015. 99-137 p.

HASHIMOTO, V.Y. et al. Occurrence of antibodies against Leptospira spp. in horses of the urban area of Londrina, Paraná, Brazil. Revista do Instituto de Medicina Tropical de São Paulo. v. 49, n. 5, p.327-330. Available from:<http://www.scielo.br/pdf/ rimtsp/v49n5/a10v49n5.pdf >. Accessed. Fev. 10, 2020.

JARA, M. et al. Spatial distribution and spread potential of sixteen Leptospira serovars in a subtropical region of Brazil, Transboundary and Emerging Diseases. v.66. n.6, 24822495,2019. Available from:< https://onlinelibrary.wiley.com/ doi/epdf/10.1111/tbed.13306>. Accessed: Mar. 25, 2020. doi. $10.1111 /$ tbed. 13306 .

JORGE, R.S.P., et al. Exposure of free-ranging wild carnivores, horses and domestic dogs to Leptospira spp. in the northern Pantanal, Brazil. Memórias do Instituto Oswaldo Cruz, v. 106, n. 4, p.441-444, 2019. Available from https://www.scielo.br/scielo. php?script=sci_arttext\&pid=S0074-02762011000400009 >. Accessed. Aug. 25, 2020.

KOIZUMI, N. et al. Molecular and serological investigation of Leptospira and leptospirosis in dogs in Japan. Journal of Medical Microbioly, v. 62, p. 630-636, 2013. Available from: < https://pubmed.ncbi.nlm.nih.gov/23264455/>. Accessed. Aug. 27, 2020. doi. 10.1099/jmm.0.050039-0.

LASTA, C.S. et al. Pesquisa de aglutininas anti-Leptospira em soros de equinos de tração em Porto Alegre, Brasil. Revista Brasileira de Ciência Veterinária. v. 20, n.1, p.23-25,2013. Available from: < https://periodicos.uff.br/rbcv/article/view/6935/5218>. Accessed; Apr, 2020. doi. 10.4322/rbcv.2014.051.

LELU, M., et al. Seroepidemiology of leptospirosis in dog communities of Los Rios Region, Chile. BMC Veterinary Research, v. 11 , n. 1, p. 31, 2015. Available from: <https://www.ncbi.nlm. nih.gov/pmc/articles/PMC4329218/>. Accessed. Aug. 25, 2020. doi: 10.1186/s12917-015-0341-9.

MENY, P. et al. Seroprevalence of leptospirosis in human groups at risk due to environmental, labor or social conditions. Seroprevalencia de leptospirosis en grupos humanos en riesgo por factores ambientales, laborales o sociales. Revista Argentina de Microbiología, v. 51, n.4, p. 324-333, 2019. Available from: < https://www.elsevier.es/es-revista-revista-argentinamicrobiologia-372-pdf-S0325754 1 19300069>. Accessed: 8 April, 2020. doi: 10.1016/j.ram.2019.01.00.

YAN, W. Et al. Experimental Leptospira interrogans serovar Kinnewicki infection of horses. Journal Veterinary Internal Medicine, v.24, p.912-917, 2010. Available from: < https://onlinelibrary.wiley. com/doi/full/10.1111/j.1939-1676.2010.00507.x>. Accessed: Mar. 20, 2020. doi: 10.1111/j.1939-1676.2010.00507.x. 